\title{
The Steppe that Ceases to Be Itself: Migration and Attachment to Homeland Among the Nogais in Dagestan, North Caucasus
}

\section{Abstract}

In Dagestan, the Nogais - descendants of the famous Golden Horde - live mostly in the Nogai District, as well is in neighboring territories that administratively belong to Chechnya and Stavropol Krai; taken together, these territories form one geographical entity, known as the Nogai Steppe. A paradoxical situation is that despite heavy migration pressure and the fact that much of the labor force from the District works - either temporarily or permanently - in other Russian regions, the District capital - Terekli-Mekteb - is rapidly expanding. One of the reasons for this is that migrants build houses "for the future" - not to live in them now but with a view to inhabiting them once they come back after retiring. In this paper, based on ethnographic fieldwork research, I analyze how the Nogais - be it dwellers of the Nogai Steppe or economic migrants - maintain attachment to what they call "the land of the ancestors". I argue that different forms of this attachment constitute a way of social mobilization in unfavorable political and economic conditions. Thus, they are intended to strengthen the position of the Nogais in the Nogai Steppe, in other words - to preserve its Nogainess.

Keywords: Nogais, Nogai Steppe, Dagestan, land, transhumance, desertification, migration, urbanization

\section{Introduction: The White Sun of Nogai}

In a dramatic introduction to the documentary The White Sun of Nogai (dir. Isakaev 2017), a young man wanders through a desert. One can guess he is in a grim situation: running out of water, he crawls up a hill and eventually falls down. He is 
lost in a desert that has no end, he is facing death. In the next scene, in a narration style known from nature documentaries, a narrator speaks about the Gobi Desert in Mongolia - the environment barely habitable to most sorts of life, including humans. Finally, another young man appears on the dune. He reveals that the presented sceneries are not the Gobi at all. As a matter of fact, they are territories of the Nogai Steppe, Republic of Dagestan, North Caucasus, Russian Federation. For a number of reasons, the Steppe is undergoing a process of desertification, which in turn has a damaging effect on the environment and local population. Addressing those problems was the main idea of the documentary.

At the same time, besides the ecological dimension, the goal of The White Sun of Nogai was deeply political. The movie was made in connection with the All-Russian Convention of the Nogais that took place in June 2017 in Terekli-Mekteb, the center of the Nogai District in Dagestan. The convention, in its turn, was sparked by new law regulations on land issues - or, to be more precise, a press leak about new regulations - that the Dagestani government wanted to introduce. The regulations would be deeply harmful to the Nogais, so in order to oppose them, they managed to organize - within a few weeks from the press leak - an event for more than four thousand participants, who came from different Russian regions and abroad. The convention shows that the land, i.e. the Nogai Steppe, is of utmost importance to the Nogais. Moreover, it proves their enormous potential for social mobilization.

The various conflicts around land point to several vital social problems in Dagestan: complex interethnic relations; substantial migration flows; corruption schemes; social and economic inequalities; tense relations between federal and republican-level authorities on the one hand and republican-level and local selfgovernments on the other. When it comes to the Nogais - as I am going to show the relationship to the land lies at the heart of their self-perception, construction of ethnic identity, and cultural and ethnic heritage. This relationship, however, is being seriously challenged and is wrought with many paradoxes.

One of them has to do with the intense pressure to migrate on the native population of the Nogai Steppe. As much as 30\% of inhabitants of the Nogai District are estimated to temporarily or permanently work in other Russian regions, mostly in the Tyumen Oblast'. At the same time, however, Terekli-Mekteb is rapidly expanding. People build houses, mosques as well as public infrastructure, such as roads, water mains or playgrounds for kids. They do so - and this is characteristic of other regions of Dagestan as well - usually without any support from the state or from abroad, out of a strong attachment of the Nogais to their land, the "land of the ancestors" as they often call it. Even those who have been working in other Russian regions for years build houses for themselves in Dagestan just "for the future", in hope that one day, perhaps after they retire, they will come back. As I frequently heard from my interview partners, "after all, you should be buried in your homeland". 
In this article, I argue that various ways of maintaining the connection of economic migrants to their homeland, along with different forms of urbanization, constitute a form of social mobilization, intended to preserve the Nogainess of the Nogai Steppe. Harmful legal regulations on the usage of the Steppe as well as its desertification - which I will discuss in detail below - are perceived by the Nogais as parts of the centuries-long process of persecution and expulsion of their group from its territories. Attachment to the Steppe thus gradually became the key factor of Nogai ethnic identity, in as far as they consider keeping it theirs a matter of cultural survival.

This study presents some results of two ethnographic fieldwork trips to Dagestan in 2018 and 2019. ${ }^{1}$ I supplement the empirical material gathered in the field such as semi-structured personal interviews, photographic documentation, observations and notes taken when visiting people's homes - with other sources: phone calls and interviews taken via video conferencing applications, scholarly literature on the subject, online reports, social media content, and visual materials posted on platforms such as YouTube.

I start with a short historical background of contemporary Nogais. The nomadic past and the great heritage of the Golden Horde are often invoked in public discussions on Nogai history and identity. Yet they do not match the difficult present, in which the Nogais are vulnerable in many dimensions. Next, I describe the issues of transhumance land, i.e. the seasonal pastures that comprise the majority of the Nogai Steppe and are rented by members of non-Nogai ethnic groups. As far as the issue has major impact on economic situation of Nogais as well as their perception of their ethnic territories, it is closely tied to the topic of the next sections: economic migrations on the one hand and the keeping by Nogai migrants of a connection with their homeland on the other. In this context, I follow the story of Begali, one of my interview partners. In conclusion, I summarize my argument and make some general comments on the attachment of the Nogais to the Nogai Steppe.

\section{The Nogais: reflecting on the glorious past}

When the White Sun of Nogai presents the Nogai Steppe as the Gobi Desert, the first purpose of this mystification - as has been said above - is to draw attention to the ecological crisis. The next scene, after the actual location has been revealed, shows a woman who lives at a sheep-breeding station (kutan). She sweeps the yard and complains about the tough dwelling conditions: constant struggle against sand and dust, no paved road access, no land-line electricity supply, neither finan-

Altogether, I spent two months in various locations of the Republic researching conflicts around land, urbanization processes, and informal economic activities. 
cial nor infrastructural support from the local government. This encapsulates in short the difficulties of living in the steppe. When wind gets stronger or turns into a sandstorm (buran), some villages get virtually covered with sand.

At a deeper level of interpretation, the reference to the Gobi Desert marks a link to the nomadic past and the great heritage of the Mongol Empire - the heritage that is often invoked in publications, discussions as well as symbols displayed in public spaces. When it comes to the animation of historical discussions and constant referring to the pre-Russian past, the so-called renaissance of ethnicity period - attributed by some scholars to the 1990s' Russia (cf. Hughes, Sasse 2001; Nowicka 2000; Treisman 1997) - is not over among the Nogais. Each person I talked to for a longer time commented on Nogai history, naming renowned people of Nogai origin, or provided dates and facts from the past. Also, on Internet forums, people were actively discussing their history and go to a lot of trouble to differentiate the Nogai legacy from the histories of other Turkic ethnicities who draw their roots back to the Golden Horde. ${ }^{2}$

The contemporary Nogai Steppe was not a part of historical Nogai states formed in the aftermath of the Golden Horde's collapse. These states did stretch their control to the North Caucasus from time to time, which in practice meant that the Nogai nomadic population pastured their flocks there. In general, however, the Nogais came to Dagestan relatively late, only in the $17^{\text {th }}$ and $18^{\text {th }}$ centuries, when in the course of continuous wars with the Russians, Kazakhs and Kalmyks, they were gradually pushed to the southern borders of the steppes between the Black and Caspian Seas (Atwood 2004: 288; Frank 2009: 244-245). Nevertheless, the contemporary Nogais view the Nogai Steppe as the last snippet of their former territories. They see their presence there as a result of many lost wars, expulsions, massive migrations and persecutions. For instance, my interview partners often mentioned the tragic year of 1783 and the Russian war campaign that ended the last Nogai state in the Kuban region, leaving dozens of thousands of Nogais dead and forcing more than 100,000 people to flee to the Ottoman Empire (cf. Karpov, Kapustina 2011: 331). It is a bitter irony that today even the Nogai Steppe ceases to be Nogai.

\section{The Nogai Steppe and transhumance land}

In demographic terms, the Nogai Steppe is the area of compact dwelling of the Nogais geographically located on the arid plain between the Terek and Kuma Riv-

2 For instance, on one Facebook forum, a man spontaneously proposed a coat of arms of his invention for the Nogai District. It depicted a horseman with a hunting falcon on his arm. Additionally, a yurt crown was added in the corner. There were dozens of comments under the picture, mostly critical ones. Disappointed participants of the forum complained that the picture "draws too much on the Kazakh symbolism" or "is too Kyrgyz". 
ers. Nevertheless, since 1957, the Steppe spans across three Russian administrative regions: most of it belongs to Dagestan, with minor pieces in Stavropol Krai and the Chechen Republic. The Nogais, therefore, feel divided. For decades now, they have been calling for the creation of an autonomous Nogai political entity, just like the ones enjoyed by many other ethnic groups in Russia, be it at the level of a republic or an administrative okrug. In other words, even though the Nogais are the majority in the Nogai Steppe, they are not the autonomous hosts of it but fall under the jurisdiction of three different administrative regions.

Second, it seems that the Nogai Steppe is losing its very name. In their recent press statements, the authorities of Dagestan - even when acknowledging the problem of the desertification - tend to avoid using the phrase "the Nogai Steppe". Instead, they include the Steppe into a broader and vague category of "the Kizlyar pastures and chernozem lands" (e.g. Obshchestvennaya palata Respubliki Dagestan 2017). The Dagestani Nogais interpret it as a next step towards violating their possessions and heritage.

Finally and most importantly, even in the Nogai District - the administrative sub-unit within Dagestan where the Nogais are the nominal hosts - in fact they do not control the majority of the district's territory. This is because of the so-called transhumance land or transhumance pastures (zemli otgonnogo zhivotnovodstva; otgonnye pastbishcha). The functioning of the state-organized transhumance system in Dagestan dates back to the 1920s. Nonetheless, it operated at its peak in the in the 1950-1980s, when it was coupled with development of the kolkhoz system and the policy of massive resettlement of the highland population to the plains (Karpov, Kapustina 2011: 115-121). In short, it consisted in pasturing the flocks predominantly sheep but also some cows and horses - from approximately October to May in the plains and transporting them to mountain valleys for the summer time. The system of cattle husbandry as well as its transport was supported by the state and seemed to work well; not without substantial environmental costs, though (Zalibekov, Kusov 2003).

The legal status of the transhumance land is extremely complex and dynamic (cf. Akmanbetov 2019a, 2019b). On the one hand, throughout the post-Soviet decades, it has been a matter of conflicts of interests between the Republican-level government and the self-governments within whose borders the pastures lie. On the other, it has been the object of legal negotiations and power struggle between the Republican and federal-level governments. In general, the pastures in the lowlands are rented by highlanders (represented by district self-governments), who otherwise would have neither the feeding capacity nor space to keep their flocks. This circumstance introduces an ethnic dimension to the whole situation.

In Dagestan as a whole - the most heterogeneous Russian region when it comes to ethnicity and language - the Nogais comprise roughly $1.4 \%$ of the population. This ranks them $10^{\text {th }}$ among the national and ethnic groups living in the Repub- 
lic (Naseleniye Dagestana 2020; Vserossiyskaya perepis' naseleniya 2010). ${ }^{3}$ Those that rent the transhumance pastures, in turn, belong mostly to the biggest groups, i.e. the Avars $\left(29.4 \%, 1^{\text {st }}\right.$ position in Dagestan) and the Dargins $\left(16.5 \%, 2^{\text {nd }}\right.$ position). Even though the pastures administratively belong to local districts, all the rental agreements - just like all the financial flows concerned - are under the control of the Republic's government, in which highland groups are the most influential. This creates a peculiar situation. Transhumance land comprises as much as $65.7 \%$ of the territory of the Nogai District (exactly 582,000 out of 887,000 hectares) (Akmanbetov 2019a: 44). Thus, the majority of the District's area is used by other ethnic groups for cattle husbandry and the local authorities neither control the usage nor receive any taxes from the economic activities performed there.

What is more, in recent decades, the transhumance system has become obsolete and nowadays remains largely a fiction. From both ethnographic interviews and literature on the subject one conclusion is clear: today, almost no one transports their flocks to the mountain valleys for the summer - even though herders receive government subsidies for this purpose. Flocks stay generally in the lowland steppes all year long. Additionally, because of non-compliance to pasturing norms, the flocks are too big. Both kinds of practices are violations of existing legislature. All in all, it is the anthropogenic factor that constitutes the main cause of the desertification of the Dagestani steppes. Being used throughout the year and too extensively, the steppes suffer from erosion due to overgrazing (cf. El'darov 2010; Nasyrov, Akmanbetov 2019; Zalibekov, Kusov 2003).

The Nogais add the transhumance problem to the long list of their martyred history, along with subjugation, extermination, expulsion from their lands, etc. The 2017 All-Russian Convention of the Nogais - which was mentioned at the beginning of this article - was sparked by the news that the Republican-level government intended to transfer ownership of transhumance pastures to the highland districts that rented them. That would mean the Nogais would have to give up all claims to much of the area of the Nogai Steppe. At the convention, participants would speak of a genocide that was being perpetrated against the Nogais (Adiev 2017; Akmanbetov 2019b: 372). The transhumance problem - being a part of broader relationship of the Nogais to their homeland - became a centerpiece of Nogai ethnic and cultural survival.

3 According to the 2010 census, there were 103,660 Nogais in the Russian Federation, dispersed across the country. 40,407 of them lived in Dagestan, including 19,556 in the Nogai District. 


\section{"We still nomadize, only now to Surgut"}

Most nomadic peoples of the North Caucasus settled in the $19^{\text {th }}$ century with last forced to do so under the Soviet collectivization policy of the 1920s. The nomadic way of life among the Nogais was thus abruptly broken and today, after a century, no one can claim any vital connection to it. A connection, nevertheless, is maintained in several ways: for instance, making historical references in public disputes, invoking cultural legacy, or revering the past in folklore and ethnographic museums. All these ways contribute to the construction of a certain image of the steppe that, in turn, is used to strengthen Nogai political claims. Attachment to nomadism is not only symbolic, though. If you ask someone about the presence of nomadic legacy, the answer you might get is: "we still nomadize, only now to Surgut".

The city of Surgut and other locations in the Khanty-Mansi Autonomous Okrug are the most popular destination of Nogai economic migration. Other popular Siberian destinations - because of the oil, gas and mining industries are Novy Urengoy in the Yamalo-Nenets Autonomous Okrug and Norilsk in the Krasnoyarsk Krai. ${ }^{4}$ In the assessment of my interview partners, big urban centers of European Russia came in only on at $3^{\text {rd }}$ or $4^{\text {th }}$ place in terms of the size of the Nogai diaspora. According to the information obtained personally from the administration of the Nogai District, as much as 30\% of the district's working population is estimated to work - temporarily or permanently - in other Russian regions. The economic migration flows in Dagestan are not monitored, however, and no reliable data are available on the numbers and destinations of those flows. ${ }^{5}$ When I asked my host about his neighbors living on the same street, in the vast majority of some 20 households he mentioned, someone either worked outside Dagestan or had an experience of economic migration.

While in the recent 20 years economic migration out of Dagestan increased in numbers, by no means is it an exclusively post-Soviet phenomenon. For centuries, Dagestani mountain craftsmen would come to the plains and wander to neighboring regions in order to sell their services and products. In the Soviet times,

4 According to the 2010 census, there were altogether 8,888 Nogais living in the Tyumen' Oblast', a vast majority of them in the two oil- and gas-rich okrugs: 5,323 in the Khanty-Mansi Autonomous Okrug and 3,479 in the Yamalo-Nenets Autonomous Okrug. These numbers refer only to permanent and registered dwellers (living with propiska), not to temporary workers employed there. The total numbers of actual permanent dwellers, including those unregistered, are considered to be much higher - up to 30,000 of Nogais living in the Tyumen' Oblast' (Sokolov 2017: 181). The latter number would comprise roughly $30 \%$ of all Nogais in the Russian Federation.

5 Yuri Karpov and Ekaterina Kapustina assess that in locations researched by them, from 10 up to even $75 \%$ of the adult population engaged in temporary or permanent economic migration out of Dagestan. The percentage of people involved was higher in the mountainous areas and relatively lower in the plains (Karpov, Kapustina 2011: 163-164). 
seasonal migrants went to harvest agricultural produce in the Stavropol Krai and other southern regions. Apart from this, construction and industrial sites in Georgia, Azerbaijan, and the Central Asian republics (mostly the Turkmen and Uzbek SRRs) would attract large brigades of workers from Dagestan. Since the 1960s the Nogais and the related Turkic group of the Kumyks started heading to Siberian destinations since the 1960s. All in all, the migrations involved several hundred thousands of people (Karpov, Kapustina 2011: 112-114).

As for the contemporary dwellers of the Nogai District, among the main reasons to migrate, they listed political and economic inequalities, unemployment, low wages, limited possibilities for career advancement for the youth, corruption, and ecological problems caused by the desertification of the steppe. This corresponds with migration incentives characteristic to Dagestan in general (cf. El'darov et al. 2007; Sokolov 2017: 176).

To give some illustration of the specificity of labor migration of the Dagestani Nogais, let me relate the story of one of my interview partners, a 32-year-old man named Begali. ${ }^{6}$ Having graduated from high school in the Nogai District, he left for Moscow to work on construction sites. As he put it, "I worked as a laborer, an illegal one (ya rabotal chernorabochim, nelegalom)", meaning that he performed non-qualified, low-paid jobs and did so informally - he was just 17 at that time and worked without residence registration in the city (propiska). He lived in Moscow for some 10 years and worked at a number of different places - a meat processing plant, warehouses and supermarkets - until he "got on his feet" (vstal na nogi). He looked for a Nogai girl on social networks and finally found one. They got married and had two kids. He also started to study to become what he really wanted: a journalist. He successfully finished his studies despite having to work at the same time, as he had to provide for his family. Finally, the whole family came back to Dagestan; not to Terekli-Mekteb, however, but to Makhachkala. Begali started to work as a journalist there, his wife found a vacancy in a private kindergarten.

Nonetheless, as it turned out soon, it was difficult for them to make a living in Makhachkala. Their salaries were not enough to rent an apartment, to pay the bills, and in general to maintain a living standard they expected. Begali thus decided to take up a job "in the North" (na Severe). Through a fellow Nogai he found employment in Usinsk, Komi Republic, fixing oil mining machinery. Depending on the location and type of industry, work in the North is permanent or based on a shift system (vakhtovaya sistema). The length of shifts depends on the working conditions, the company, individual contract, etc. The working shift and resting period are usually of the same length, so for instance you work for two weeks and then you have two weeks off; or one month of work - one month off. The pace is intense: you work seven days a week, 12 hours a day. Begali worked 2-month

\footnotetext{
6 The name is a pseudonym invented by me in order to protect his anonymity.
} 
shifts, so he was away from his family for longer periods of time. Nevertheless, he was satisfied.

Salaries in the North are high, especially in comparison to Dagestan, where wages, at least officially, are well below the Russian average (cf. Sergeev 2020). While according to my interview partners, in Makhachkala you earn 20,000 rubles per month on average (it is less in the Dagestani provinces), in the North you get paid 60,000-70,000 for a low-qualification job, while specialists or workers with substantial experience get 100,000-120,000 per month and additional benefits. What is more, your employer usually provides you with housing and food, so your costs are very small. ${ }^{7}$ For Begali, his wage of 70,000 rubles was enough to comfortably provide for his family. Between shifts, he would come back to Makhachakala and engage in the journalist part of his professional life, working out of interest and for self-development rather than strictly money.

Recently, Begali's family has moved back to Terekli-Mekteb. They did so because of the kids and high costs of living in Makhachkala. They had big problems with placing the children in a kindergarten. They managed to put the older child in the kindergarten that Begali's wife worked in, for a lower fee. This proved impossible for the younger one, though as in order to place the second child in a public kindergarten, they would have to pay a bribe of up to 100,000 rubles. $^{8}$ Reluctant to do so they decided to move to Terekli-Mekteb, where kindergartens are more available and they could count on the help of their parents.

In many respects, the story of Begali is typical of economic migrations not only for the Nogais but also other Dagestani ethnic groups. Departing for economic reasons, choosing a destination of migration and finding a job through ethnic ties; tough beginnings and problems with registration, marrying a woman of the same ethnicity, coming back to Dagestan - not to the home village but to Makhachkala (as it offers better jobs and social services than the countryside the migrants often come from), taking up a job in the oil industry in the North: these points appear in many biographies of Dagestani economic migrants (cf. Kapustina 2017, 2019: 114; Karpov, Kapustina 2011: 195-197; Oparin 2017: 259-260; Sokolov 2017: 178-181; Yarlykapov 2008). What is more, Begali - with his labor mode of work-

7 It can be added here that while most Nogai economic migrants go to other Russian regions, some of them take up jobs abroad. One of my interview partners worked in Belarus (in a shift system) installing a ventilation system in a nuclear power plant. He earned some 100,000 rubles per month; additionally his employer covered a lot of expenses, such as housing, travel, and food. We talked while he was in the Nogai District, waiting for another work call. He was supposed to go to the Philippines next.

8 Virtually every married couple who had kids told me about their problems finding a kindergarten in Makhachkala. In terms of demographics, Makhachkala is one of the fastest growing cities in Russia. However, the number of public educational facilities (not only kindergartens but also schools) is not adjusted to the number of inhabitants. Places in kindergartens are a scarce good, and as such are subject to corruption. 
ing in shifts - may serve as an example of what has been dubbed "parallel living": in Dagestan and in the North (Sokolov 2017).

What seems specific to Begali's story, is his pursuit of an education and personal growth. As he put it, he needed to do something other than working just for financial profit "in order not to get dumber" (chtoby ne otupet'). On the one hand, this differentiates him from a rather standard migrant strategy of working, and earning, as much as possible. On the other, however, in his perception, it was his education that enabled him to serve his community in a better way. Indeed, even though Begali did not directly engage in politics, through his press and social media reports he supported Nogais' claims, publicized their dire situation - including materials on the transhumance land problem, and overall strengthened the cultural identity of his group.

\section{Maintaining connection: urbanization "for the future"}

The massive migration flows do have their impact on the Nogai District and the Nogais. While the majority of - if not all - migrants intend to come back home, many of them ends up settling permanently outside of Dagestan. Plans (or dreams) to return home may be called a certain "myth" (cf. Karpov, Kapustina 2011: 196), as the decision to do so is sometimes postponed for decades. Jobs that initially were taken up just "for a short time" or "just to make some money" - turn out to last for decades. A large portion, perhaps the majority, of migrants stays in their work locations for years. They buy apartments there, raise their children and send them to schools. Obviously, this process causes a constant outflow of population and changes to the local demographic composition, as it is predominantly members of the young and middle-age generations that leave. ${ }^{9}$

More specifically, the migrations have a grave impact on family ties. If one of the spouses works thousands of kilometers away for months or even years on end, those marriages often break up. If both of the parents work in Surgut and they come back home only for summer, the children stay with their grandparents. As a result, according to stories I heard, kids would sometimes not recognize their parents. If the whole family leaves, this affects younger generations, as well. They are subjected to transitional stress because of the change of schools and the necessity to adjust to a new environment, both physical and social one.

Moreover, migrants are prone to what is called obrusenie (getting Russified; obruset" - "to get Russified"). Obrusenie is a pejorative term that denotes losing one's ethnic and cultural identity - language, religion, way of life, style of dress, etc. - in effect becoming ethnic Russian lookalikes. If children change environ-

9 It seems, however, that the migrations do not change the local gender composition significantly, as both men and women migrate. 
ment, they are more likely to assimilate quickly. Soon, as many of my interview partners complained, they do not want to speak their ethnic languages but preferring to communicate only in Russian. ${ }^{10}$ The parents are affected by changes, too. They can be subtle (e.g. you talk to someone outside your house and you do not invite the person inside) or more serious (e.g. you do not comply with religious principles anymore), nevertheless they are noticeable to the people who knew you before you left. ${ }^{11}$ The Nogais usually count such changes among the negative consequences of assimilation. All in all, these phenomena cause a lot of anxiety among older generations, as they raise questions about the character and indeed existence of the Nogais in the future (cf. Yarlykapov 2008: 80). Also, the Internet is full of discussions about the endangered Nogai identity, the issues of Nogai language, tradition and land being most often touched upon.

At the same time, the attachment of the Nogai migrants to their homeland manifests itself not only in their dreams to return there one day. They maintain a vivid connection. Modern communication technologies make it much easier to spread information, make phone calls, send packages, or make money transfers all of which was problematic or burdened with high financial costs as recently as 10 years ago.

Even physically, due to developed airline routes, traveling is now quick. For a price much smaller than the airplane connection, a minibus shuttles between Terekli-Mekteb and Moscow four times a week. After all - according to Russian measures - it is not that far: in some 24 hours you can be in the Russian capital. Transport vehicles connect the Nogai District also to much further destinations, though they deliver goods rather than people. And so, vans go regularly to places like the Komi Republic or the Tyumen' Oblast packed with lamb and other foodstuffs. The deliveries are targeted not only at Nogai workers who highly appreciate the Dagestani meat, contrary to industrially processed meat products that are predominant in Russia. The meat is enjoyed and gladly bought by workers of other ethnic origins, too. Thus, the van operators developed their deliveries into a successful business. Dagestani goods exported in this way are not limited to food. For instance, a Nogai family from Surgut ordered furniture for their apartment. They found it better, perhaps also cheaper, to transport it from Dagestan than to buy it locally. This applies also to other craft products. The price, even though important, does not always play the decisive role, as it is the Nogainess or Dagestaniness of the products that counts. ${ }^{12}$

10 The loss of the ethnic language often takes place without any migrations. On many occasions, I personally witnessed a situation whereby the middle-aged parents spoke their ethnic language but their children already could not or would not speak it, preferring to communicate in Russian.

11 These examples were given by one of my interview partners.

12 An interesting example that proves this perception is that even though in the region of Surgut there are plenty meat-producing enterprises, including those delivering halal products, the Dagestani migrants prefer meat imported from Dagestan (Kapustina 2017: 30). 
Paradoxically, despite the major outflow of population from the Nogai District, Terekli-Mekteb and its neighboring villages are fervently expanding. Not only individual houses but also entire new neighborhoods (mikroraion) are being developed. This often takes place quite chaotically: without a general development plan, in the middle of the steppe, with neither paved roads nor water main or electricity network access. The locations seem unfavorable, nevertheless people decide to start building there and thus in a certain sense tie their lives to the places. The people who undertake construction come from different backgrounds. In the 2000s, a neighborhood in Terekli-Mekteb was built by Nogai refugees from the Chechen wars. Nowadays, the new estates are established by both local dwellers (young married couples or older people building for their children) and economic migrants who currently work outside Dagestan.

Usually, you build first and only afterwards provide the needed infrastructure. To this end, together with your neighbors, you gather the required resources: money, labor force, administrative permits, etc. Finally, you are able to extend a local water main or power-line and connect to them all the houses in the neighborhood. In the Nogai District, just like in other regions of Dagestan, public infrastructure is developed owing to people's resourcefulness, usually with hardly any help from the state (cf. Kaliszewska 2019; Kapustina 2019: 113-114).

Another paradox is that the newly constructed houses often stay uninhabited. The owners work in other Russian regions, so they come to Dagestan only from time to time, perhaps only for the summer. Therefore, they ask a cousin or a neighbor to take care of the house while they are away. Especially crucial is heating during the winter: someone has to come and regularly fire up the furnace, otherwise mold will quickly appear on the walls. The houses are built "for the future" - when their owners return from emigration. As has been pointed out above, many migrants live in a short-term temporality, constantly considering yet postponing their return to Dagestan. If they eventually decide to come back, they do it only once their offspring become independent or after they themselves retire. Thus, the houses may stay empty for years but they serve the Nogai migrants as a kind of an anchor to their homeland.

Current Dagestani urbanization is not limited to residential development only. In the Pobeda district of Terekli-Mekteb, local dwellers got a plot of land from the urban administration, on which they built a playground, sports pitch and an open-air gym station. They also fenced the whole area so as to prevent animals from entering. In the village of Karagas, in turn, people renovated two rooms in the old, decrepit cultural center building $(k l u b)$. One of those they turned into a wrestling training hall. In another they installed a bodybuilding gym. They also hired a trainer to work with the youth there. Moreover, in one of the rooms in the local school, a Nogai ethnographic exhibition was opened. People brought the exhibits from their own homes. These are but a few examples of collective action and application of social capital which unites both local dwellers and economic migrants living outside Dagestan, as it was the latter who supported the 
projects financially. All of that constitutes yet another sign of people's attachment to their homeland and their propensity to fix the Nogai presence there.

\section{Conclusions: "You should be buried in your homeland"}

As I have showed in this article, the nomadic past is still present in the historical imagination of contemporary Nogais. Once united in the Nogai Horde, over the course of history, they found themselves dispersed across the southern regions of Russia. More recently, due to economic migrations, their sizeable diasporas have appeared in the Tyumen' Oblast and other Siberian locations. In the Nogai Steppe, the situation of ethnic Nogai territories is problematic because of the transhumance pastures used by other, more powerful Dagestani ethnic groups. This fact, along with the negative consequences of economic migrations and social changes, raises questions about the future identity of the Nogais, in its political, cultural, linguistic and other dimensions. Addressing those questions, the Nogais even those living outside Dagestan - express their attachment to their homeland in manifold ways. This shows a tendency of establishing new ways of identification with one's place of origin, ways that form translocal villages and communities (Kapustina 2019).

The causes of migration from Dagestan go beyond the immediately economic ones, as they are a continuation of long-term historical processes (Karpov, Kapustina 2011: 165). The same statement can be made about the reasons for coming back, especially if one speaks about the Nogais and the Nogai Steppe. While the migrants leave for reasons including political inequality and ecological problems, their reasons to return can be labelled strictly cultural ones. They involve such notions as home, the land of the ancestors, and historical legacy.

The specificity of the Nogai migrations seems to lie exactly in the broadly understood cultural dimension. It is formed at the peculiar intersection of economic and political situation of the Nogais and their efforts to preserve ethnic and cultural identity. The fact that they do not possess either their own statehood or developed forms of coherent regional autonomies distinguishes the Nogai economic migrations and their implications from the ones undertaken by the Central Asian nationalities to Russia, including the same destinations in the North, for instance. By migrating and living outside Dagestan, the Nogais fear losing the very grounds for being perceived as a separate group, such as language, group cohesion or territory. As has been discussed above, the danger that the Nogai Steppe will cease to be itself is real. Hence Nogai efforts to maintain a connection with it despite the heavy pressure to migrate; the rapid urbanization of Terekli-Mekteb that comprises of building houses "for the future" can be seen as an example of this tendency. However, as I have shown in this paper, the process of marking the Nogai space takes place not only in the material but also in the symbolic sphere. 
According to an old custom present among Nogai nomads, when a child was born in a camp, one poured a few drops of its umbilical cord blood onto the ground. This was meant to tie the life of the person to the place s/he was born. And to this day many, perhaps all, Nogais would agree that "if you have to die, you should die in your homeland" or, should you meet other fate, then at least "you should be buried in your homeland". Indeed, if a Nogai person dies away from their community, their relatives spare no efforts or money to bring the body home and bury it at a local cemetery. In this symbolic way, the two key moments of human life - its beginning and its end - are connected to a special area, the land of your ancestors. ${ }^{13}$

As surprising as this may sound, the ancestors that had passed away long time ago now physically appear in the Nogai Steppe. In a shocking scene in the White Sun of Nogai, people find human bones in a desertified part of the Steppe. This happens all across the area because of erosion, deflation, and oversized herds. As the surface level of the soil erodes due to overgrazing, the strong winds gradually flatten old burial mounds and uncover the skeletons inside. The very fact that herds are pastured on the old cemeteries is disturbing. That is why - as I was told some of the cemeteries in the steppe got fenced. In the documentary, people gather the bones - apparently coming from different bodies - and bury them again in a common grave. The bones of the ancestors make for an ultimate omen, an appeal to the living that the homeland is in crisis.

\section{Bibliography}

Adiev A.

2017 Zemel'naya reforma iprotesty $v$ Nogayskom rayone Dagestana (analizsobyti 2017g.), "Vlast", pp. 181-186.

Akmanbetov A.

2019a Ob otgonnykh pastbishchakh in: R. Nasyrov, A. Akmanbetov (eds.), Ob otgonnykh pastbishchakh Respubliki Dagestan na primere Nogayskogo rayona, pp. 8-53.

2019b O pravavom regulirovanii problemy otgonnogo zhivotnovodstva v Respublike Dagestan in: N.Ch. Suyunova et al. (eds), Nogaytsy: XXI vek. Istoriya. Yazyk. Kultura.

Ot istokov - k gryadushchemu, Karachaevsk, pp. 368-374.

Atwood C.P.

2004 Encyclopedia of Mongolia and the Mongolian Empire, New York.

13 Both the old custom of pouring drops of umbilical cord blood onto ground and current obligation to bury the deceased in their homeland is not restricted to the Nogais only and pertains also to other ethnic groups living in Dagestan and the North Caucasus in general. For instance, one of the main tasks of cultural associations of migrant Dagestani and Chechen communities in the North is to collect funds and organize transport of the bodies of deceased compatriots back home (cf. Kapustina 2017: 31; 2019: 111-112; Sokolov 2017: 187). 
El'darov E.M.

2010 Nogayskaya step’. Available at: https://welcomedagestan.ru/dagestan/nogajskij/ nogajskaya-step/ (access: 26.07.2020).

El'darov E.M. et al.

2007 Resettlement and Migration in Post-Soviet Dagestan, "Eurasian Geography and Economics”, vol. 48 (2), pp. 226-248. doi: 10.2747/1538-7216.48.2.226.

Frank A.J.

2009 The western steppe: Volga-Ural region, Siberia and the Crimea in: N. Di Cosmo, A.J. Frank, P.B. Golden (eds.), The Cambridge history of inner Asia: The Chinggisid Age. Cambridge, pp. 237-259. Available at: https://doi.org/10.1017/CHO9781139056045 (access: 1.10.2020).

Hughes D.J., Sasse G.

2001 Ethnicity and Territory in the Former Soviet Union: Regions in Conflict, LondonNew York.

Isakaev D.

2017 Beloye solntse Nogaya. Available at: https://www.youtube.com/ watch?v=4nZiNRCbIqY (accessed: 10.10.2020).

Kaliszewska I.

2019 Sacred sites and not-so-dirty money in Dagestan, North Caucasus, "Journal of Ethnology and Folkloristics”, vol. 13 (2), pp. 137-139. doi: doi.org/10.2478/jef-2019-0021.

Kapustina E.L.

2017 Mezhdu Severom i zemley: doroga iz Zapadnoy Sibiri v Dagestan kak element sotsial'nogo prostranstva translokal'nogo migranta, "Sotsiologicheskiye issledovaniya", vol. 5, pp. 26-34.

2019 The Boundaries of the Djamaat: The Particular Features of Dangestan's Translocal Communities in the Context of Migration Flows Within the Russian Federation, "The Journal of Social Policy Studies”, vol. 17 (1), pp. 103-118. doi: 10.17323/727-06342019-17-1-103-118.

Karpov Y.Y., Kapustina E.L.

2011 Gortsy posle gor. Migratsionnye protsessy v Dagestane $v$ XX - nachale XXI veka. Ikh sotsial'nye i etno-kul'turnye posledstviya i perspektivy. Sankt-Peterburg.

Naseleniye Dagestana

2020 Wikipedia. Available at: https://ru.wikipedia.org/w/index.php?title=\%D0\%9D \%D0\%B0\%D1\%81\%D0\%B5\%D0\%BB\%D0\%B5\%D0\%BD\%D0\%B8\%D0\%B5_\%D0\% 94\%D0\%B0\%D0\%B3\%D0\%B5\%D1\%81\%D1\%82\%D0\%B0\%D0\%BD\%D0\%B0\&old $\mathrm{id}=109273846$ (access: 3.10 .2020 ).

Nasyrov R., Akmanbetov A.

2019 Ob otgonnykh pastbishchakh Respubliki Dagestan na primere Nogayskogo rayona.

Nowicka E.

2000 Wielka Syberia małych narodów, Kraków.

Obshchestvennaya palata Respubliki Dagestan

2017 Sostoyaniye Chyornykh zemel' i Kizlyarskikh pastbishch v svyazi s ikh degradatsiey, vyrabotka mer po bor'be s opustynivaniyem, obespecheniye ekologicheskogo blagopoluchiya. Available at: http://www.opdagestan.ru/news/item/412 (access: 8.10.2020).

Oparin D.A.

2017 Locals and immigrants on the Yamal Peninsula. Social boundaries and variations in migratory experience, "Asian Ethnicity", vol. 19 (2), pp. 251-269. doi: 10.1080/14631369.2017.1386543. 
Sergeev O.

2020 Srednaya zarplata $v$ Rossii po regionam in 2019-2020. Available at: https://visasam.ru/russia/rabotavrf/zarplaty-v-rossii.html (access: 7.10.2020).

Sokolov D.

2017 Ugra, the Dagestani North: anthropology of mobility between the North Caucasus and Western Siberia in: M. Laruelle (ed.), New Mobilities and Social Changes in Russia's Arctic Regions, London and New York, pp. 176-193.

Treisman D.S.

1997 Russia's "Ethnic Revival": The Separatist Activism of Regional Leaders in a Postcommunist Order, "World Politics", vol. 49 (2), pp. 212-249.

Vserossiyskaya perepis' naseleniya 2010

no date. Available at: https://rosstat.gov.ru/free_doc/new_site/perepis2010/croc/perepis_itogi1612.htm (access: 3.10.2020).

Yarlykapov A.A.

2008 Neft' i migratsiya nogaytsev na Sever, "Etnograficheskoye obozreniye", vol. 3, pp. $78-81$.

Zalibekov Z., Kusov O.

2003 Nogayskaya step’. Available at: https://www.svoboda.org/a/24196737.html (access: 30.07.2020). 